\title{
Does a more complex service offering increase uncertainty in operations?
}

\section{Kreye, Melanie}

Published in:

International Journal of Operations and Production Management

Link to article, DOI:

10.1108/IJOPM-01-2018-0009

Publication date:

2019

Document Version

Peer reviewed version

Link back to DTU Orbit

Citation (APA):

Kreye, M. (2019). Does a more complex service offering increase uncertainty in operations? International Journal of Operations and Production Management, 39(1), 75-93. https://doi.org/10.1108/lJOPM-01-2018-0009

\section{General rights}

Copyright and moral rights for the publications made accessible in the public portal are retained by the authors and/or other copyright owners and it is a condition of accessing publications that users recognise and abide by the legal requirements associated with these rights.

- Users may download and print one copy of any publication from the public portal for the purpose of private study or research.

- You may not further distribute the material or use it for any profit-making activity or commercial gain

- You may freely distribute the URL identifying the publication in the public portal

If you believe that this document breaches copyright please contact us providing details, and we will remove access to the work immediately and investigate your claim 


\title{
Does a more complex service offering increase uncertainty in operations?
}

\author{
Melanie E. Kreye* \\ Department of Management Engineering, Technical University of Denmark
}

Accepted for publication to the International Journal of Operations \& Production Management

* Corresponding author: Email: Address: DTU Department of Management Engineering; Produktionstorvet, Building 424; 2800 Kgs. Lyngby; Denmark Telephone: +45 45256028 


\title{
Does a more complex service offering increase uncertainty in operations?
}

\author{
Abstract \\ Purpose: This paper investigates how the complexity of the service offering \\ (service complexity) affects the uncertainty during service operations in \\ engineering services. Specifically, we compare the existence of organisational, \\ relational, environmental, and technological uncertainty in maintenance services \\ and performance-based services.
}

Design/methodology/approach: We present insights from four cases - two each for maintenance services and performance-based services. The in-depth data was based on 56 semi-structured interviews, multiple site visits, meeting notes, service contracts, and other secondary data.

Findings: The case findings indicate that organisational and relational uncertainty were not linked to service complexity, while observations of environmental and technological uncertainty were higher and more varied for performance-based services. Based on these findings, we formulate four propositions regarding the relationship between service complexity and uncertainty in service operations.

Originality: This research contributes to the OM literature by suggesting that external sources of uncertainty increase with increasing service complexity, while internal sources of uncertainty remain unchanged.

Keywords: engineering services, uncertainty, servitization, case study, ProductService System, complexity 


\section{Introduction}

Many manufacturing companies engage in engineering services which they add to and integrate with their existing product portfolio (Kastalli and Van Looy 2013). This trend known as servitization (Vandermerwe and Rada 1988) offers high potential benefits (Wise and Baumgartner 1999, Mont 2002, Vargo 2008). However, providing engineering services increases uncertainty exposure of service providers (Durugbo and Erkoyuncu 2016, Kreye 2017a) arising from the nature of services and the specific processes of engineering services in particular. Services are uncertain by nature due to the value cocreation with the customer with uncertain timing and quality of customer inputs (Frei 2006) and difficulties of controlling output levels (Bettencourt et al. 2002). Furthermore, engineering services are particularly uncertain because the provider typically assumes responsibility for parts of the customer's processes (Nordin et al. 2011, Reim et al. 2016). This increases provider's dependence on customer operations and their internal capabilities to process and provide information (Zhang and Banerji 2017) and the customer's demand structures (van der Vorst and Beulens 2002). While engaging in servitization also increases the provider's risk exposure (Benedettini et al. 2015, Reim et al. 2016), it is uncertainty that determines the provider's ability to implement servitization successfully (Durugbo and Erkoyuncu 2016) and the service performance (Kreye 2017a).

Uncertainty is intrinsically linked with complexity (Davis 1993, van der Vorst and Beulens 2002). Complexity is generally understood to increase uncertainty because the effects of decisions are difficult to predict and complete understanding is difficult to achieve. Specifically in services, this link between complexity and uncertainty has been suggested (Argyres and Mayer 2007, Badinelli et al. 2012, Selviaridis 2016). However, 
current research lacks any in-depth investigation into this topic due to the following challenges. First, service complexity is still an emerging field with current investigations focusing on deriving a suitable definition and conceptualisation of the construct (Benedettini and Neely 2012, Zou et al. 2018). This relative immaturity of theory in this area means that research into connecting service complexity to other constructs is still relatively scarce. Second, current investigations of uncertainty have focused on specific types of service offerings such as performance-based services (Huikkola et al. 2016, Nullmeier et al. 2016). The reason for these focused investigations are that performance-based services are highly complex and thus potentially increase uncertainty (Davis 1993, van der Vorst and Beulens 2002). However, a gap remains regarding the link between service complexity and uncertainty. This is the focus of this research.

This paper investigates this link by answering the following research question: How is the complexity of the service offering (service complexity) linked to the uncertainty during service operations? Building on existing works in the OM literature, we investigate the existence of four uncertainty types: organisational, relational, environmental, and technological uncertainty. Showing in-depth evidence from four cases - two of maintenance services and two of performance-based services - this research shows a differentiated picture of the effect of complexity on uncertainty as some uncertainty types were affected by the level of complexity of the service offering while others were not. This research contributes to the service operations literature by offering in-depth and nuanced insights into the effect of service complexity on uncertainty in service operations. Specifically, we provide a conceptual framework of 
four uncertainty types which we link to service complexity and present four testable propositions based on our empirical analysis.

\section{Literature review}

The nature of the service offering creates important implications for the management of the operations required to produce, deliver, and ensure performance. This has been described extensively with regard to contract management where the complexity of the service offering requires more intensive work on ensuring compliance and performance on the provider side (Eisenhardt 1989a, Roehrich and Lewis 2014, Melander and Lakemond 2015, Nullmeier et al. 2016). Here it is specifically uncertainty that has been highlighted as one of the core issues for effectively managing operations because it determines, for example, the attributability of service performance to the provider's actions (Rindfleisch and Heide 1997, Nullmeier et al. 2016). This paper applies this logic by investigating the links between the complexity of the service offering (service complexity) on the uncertainty perception in the operation of these service.

\subsection{Service complexity in engineering services}

While it is often understood that including services into a manufacturers' business models increases complexity of operations and of the resulting offerings (Oliva and Kallenberg 2003, Tukker 2004, Lay et al. 2009, Kastalli and Van Looy 2013, Van Ostaeyen et al. 2013, Kreye et al. 2015), service complexity remains a relatively immature area. Current literature in this area focuses on discerning a relevant definition of service complexity (Benedettini and Neely 2012, Zou et al. 2018). For example, Benedettini and Neely (2012) highlighted the high number of components such as resources including 
technology, human resources and knowledge, and their interrelation within the service provision. Defining service complexity remains difficult because of the dynamic and open nature of services requiring constant adaptation to context and conditions (Badinelli et al. 2012). Engineering services provide additional challenges because of the close link to a physical product where additional complexity can arise from interdependencies with product components (Oliva and Kallenberg 2003). Thus, complexity can arise from the diversity and multiplicity of components in the service offering as well as the diversity and variability of the performed activities (Zou et al. 2018).

Due to the emerging nature of service complexity in the literature and the remaining difficulties in defining the construct and its implications, we apply a simplified representation of service complexity via a useful approximation based on the agreed service output and level of interdependence between provider and customer. Few interaction points and interdependencies between provider and customer can be found in (simple) maintenance services (Martinez et al. 2010) where the service offers an addon to the sold product to improve operational up-time and prolong product life-cycles through spare part exchange, preventative and corrective maintenance (Kurata and Nam 2013). Here, customer and provider operations are relatively independent as interactions happen on discrete events through dedicated service visits (Kreye et al. 2015). In contrast, performance-based arrangements define business models of high interdependence between provider and customer because the provider takes over whole operational functions of their product to ensure output (Kim et al. 2007, Ng et al. 2009, Settanni et al. 2016). This means that provider and customer operations are intricately linked through interdependence in terms of information processing, 
communication, access and process management (Nullmeier et al. 2016, Settanni et al. 2016, Kreye 2017b). Thus, although this represents a simplified analysis of service complexity, maintenance services and performance-based services offer two extreme points on the complexity continuum that enable in-depth investigation.

To date limited considerations have been given to the influence of service complexity on the uncertainty of service operations. The importance of uncertainty has been highlighted for services in general (Broekhuis et al. 2017) and performance-based services specifically where uncertainty has been connected to the provider's potential inability to achieve performance targets due to external (Eisenhardt 1989a, Hypko et al. 2010) or customer-dependent inputs (Kim et al. 2007, Nullmeier et al. 2016). However, a comparative analysis of the operational requirements connected to service complexity has not been described. This is a gap this paper aims to address.

\subsection{Uncertainty in providing and receiving services}

Uncertainty is defined as a potential deficiency in any phase or activity of the process, which can be characterised as not definite, not known or not reliable (Kreye 2017a). Uncertainty captures the lack of understanding and differs from risk which is defined as the possible effect of an uncertain event or situation (Harland et al. 2003). Uncertainty motivates organisational behaviour as described in the context of, for example, organisational information processing theory (OIPT) (Galbraith 1974). OIPT postulates that the internal information processing activities an organisation engages in depends on the uncertainty they perceive. This research focuses on uncertainty because of the importance to service operations (Hypko et al. 2010, Durugbo and Erkoyuncu 2016) and its central position in motivating organisational behaviour (Galbraith 1974). 
Different typologies of uncertainty can be found in the literature. One example is described by Simangunsong et al. (2016) who describe external, internal, and relational sources of uncertainty. Another example is Ulaga and Kohli's (2018) description of needs, process and outcome uncertainty in services. Furthermore Yang and Gabrielsson (2017) differentiate internal, technological, and market uncertainty. The typologies based on the sources of uncertainty have been described as theoretically sound and relevant in the context of services (Milliken 1987, Simangunsong et al. 2016, Kreye 2017a, Yang and Gabrielsson 2017). We thus utilise this approach and differentiate four uncertainty types based on their specific sources as follows: environmental, technological, organisational, and relational uncertainty.

Organisational uncertainty arises from within an organisation (Simangunsong et al. 2012) and captures the potential lack of capabilities. It has received attention within the literature because of the high importance of internal challenges in this context (Benedettini et al. 2015, Zhang and Banerji 2017). It can arise from the operational differences between service and production (Hawkins et al. 2015) with increased needs of information processing (Galbraith 2002). Organisational uncertainty can arise from the provider's inability to control quality levels (Hawkins et al. 2015) and the need for operational flexibility and heterogeneity (Kastalli and Van Looy 2013). Organisational uncertainty has been described to be particularly high for performance-based services where it is connected to uncertain maintenance costs (Hypko et al. 2010) and increased execution challenges (Reim et al. 2016). It has also been described in the context of maintenance services where the provider's inability to process information internally can affect their ability to provide the service (Kreye 2017a). Organisational uncertainty is thus a relatively mature concept within the literature. 
Relational uncertainty is the ability to predict or explain a partner's actions (Kreye 2017a). It exists because of the central importance of close relationships in services in terms of co-creating the service output (Zhang and Banerji 2017). Here, potential unintended behaviour (Rindfleisch and Heide 1997) can result in the possibility of disagreements and conflict (Yang et al. 2017). Relational uncertainty can arise from the dependence on the customer's diligence, commitment and responsibility (Léo and Philippe 2001), and the customer's changing needs (Hawkins et al. 2015). The perception of relational uncertainty can depend on the extent of the prior engagement and experience between the partners (Bastl et al. 2012). This suggests that a closer interdependence between provider and customer in performance-based services in comparison to maintenance services could create higher levels of relational uncertainty. However, this interdependence may also reduce relational uncertainty because provider and customer have aligned goals (Ng et al. 2009) and experience closer social and personal ties (Kreye et al. 2015). This research investigates the existence of relational uncertainty in relation to service complexity comparing maintenance services and performance-based services.

Environmental uncertainty reflects the unpredictability of the external environment (Milliken 1987) due to, for example, market fluctuations (Hypko et al. 2010), supply availability (Chao et al. 2009), or regulations (Goel 2007). Environmental uncertainty lies outside of the focal organisation's direct influence (Simangunsong et al. 2016). Current research has highlighted the existence of environmental uncertainty in performance-based services (Hypko et al. 2010) where it can arise from fluctuations in the availability of material, parts and tools in terms of quantity and/or timing of supply (Hypko et al. 2010, Nullmeier et al. 2016). However, it may also affect operations in 
more basic maintenance services because of the length of contractual agreements and the potential effect of external changes. This has however received less attention in the literature.

Technological uncertainty is defined as the potential change in available technology over the life time of the serviced product (van der Vorst and Beulens 2002, Kreye 2018). It can relate to technology obsolescence where product parts may not be available for replacement (Pince et al. 2015). Other issues can arise from unproven technology (Reim et al. 2016) or the interaction of new technologies with existing product features (Melander and Lakemond 2015). Technological uncertainty has not been explored in depth for engineering services - neither for maintenance services nor for performance-based services. Current insights rely on the effect of technological obsolescence (Pince et al. 2015). This research aims to extend these insights by offering a characterisation of technological uncertainty in engineering services.

\subsection{Conceptual framework}

This study focuses on investigating the link between service complexity and uncertainty in operations via the following research question: How does the complexity of the service offering affect the uncertainty during service operations? Based on the literature in the field, we investigate the concept of service complexity in terms of the operational interdependence between provider and customer which we simplify by contrasting maintenance services (relatively simple) with performance-based services (highly complex). Furthermore, we study uncertainty during service operations in terms of four uncertainty types: organisational, relational, environmental, and technological uncertainty. 


\section{Method}

We adopted a qualitative case-based approach because of the exploratory nature of this research. The lack of prior investigation into the topic with a lack of existing frameworks means that we could not formulate hypotheses (Eisenhardt 1989b). Case-based research offers the empirical evidence needed to improve understanding and build theory (Siggelkow 2007). Further, case-based research enables the researcher to immerse themselves within the empirical context of their cases and thus offers the ability for in-depth investigations into the researched phenomenon (Yin 2009). This is particularly important for engineering services where the organisational and industrial context may determine research observations (Kastalli and Van Looy 2013). Furthermore, the multiple-case design enabled the researchers to investigate the research question in a situationally grounded way while seeking a sense of generalisability (Voss et al. 2002). Thus, the multiple-case approach was suitable for the purpose of this research.

\subsection{Research design}

This paper presents insights from four case studies which consist of dyads between provider and customer in engineering services. This is a suitable research design because in services it is the systems rather than individual companies that compete (van der Vorst and Beulens 2002). The cases concerned two examples each of maintenance services and performance-based services. The case selection was based on theoretical criteria of case relevance based on the type of service offering as described in the literature (Martinez et al. 2010, Kurata and Nam 2013, Settanni et al. 2016). This selection was based on a qualitative assessment of the case offerings and emerged from 
the descriptions in case providers' marketing materials and interviews. This represents our simplified model of service complexity based on the interdependence in operations between provider and customer as described in Section 2.1. The case contexts were anonymised to protect the companies' identities. The chosen providers were examples of successful service providers with a good reputation on the market for their service offerings in addition to products. The cases were chosen based on theoretical criteria of service complexity to enable triangulation and build theory (Voss et al. 2002, Yin 2009). The specific dyads were identified during discussions with the providers based on accessibility of both provider and customer for data collection. Furthermore, the cases represent different industries where engineering services are relevant to further ensure research validity (Eisenhardt 1989b). This again supported triangulation of the insights and mitigated the influence of observer bias on the obtained findings (Voss et al. 2002). The two cases of maintenance services concerned the provision of equipment maintenance including inspections and repairing of faults and breakdowns to minimise product downtime. Case A was set in the European electronics sector and focused on the after-sales support of electrical control systems. Provider A (PA) was a globally operating manufacturer of control systems such as actuators providing service support for their own products. Customer A (CA), was a regionally operating public organisation providing water treatment and cleaning services to local residents and companies. Case B was set in the European water treatment sector and focused on the support of water pumps. Provider B (PB) was a globally operating manufacturer of pumps and provider of after-sales services including repairs and preventative maintenance. Customer $B(C B)$ was a private facilities management company operating on the premises of a national 
government building. These two cases constitute relevant examples of maintenance services described in the literature (Martinez et al. 2010).

The two cases of performance-based services concerned the provision of operations and maintenance support for product groups to ensure their functioning and availability. Case $\mathrm{C}$ was set in the chemical production industry with global operations focusing on Europe and Africa and focused on the operation and maintenance of a chemical production plant including activities such as plant operation, equipment maintenance, monitoring and intervention of the production process regarding efficiency and product quality. Provider C (PC) was an internationally operating manufacturer of plants and equipment for chemical production and provider of integrated operations and maintenance services. Customer C (CC) was a locally operating producer of chemicals which they sold to local businesses. Case D was set in the European wind energy sector and included the performance-based support of a wind park. Provider D (PD) was a globally operating manufacturer of wind energy generation equipment and offered service support. Customer D (CD) was a locally operating energy provider to the national electricity grid. These two cases represent relevant examples of performance-based services (Nullmeier et al. 2016).

\subsection{Data collection}

The cases were collected via multiple sources of evidence such as semi-structured interviews, documentation notes from multiple site visits to the companies' head offices and service sites, meetings, field notes, documentation of the organisations including the service contracts, annual reports, presentations, marketing material, and announcements on webpages and similar (Voss et al. 2002, Yin 2009). A total of 56 
interviews were conducted ( 10 for Case A, 16 for Case B, 17 for Case $C$, and 13 for Case

D) across provider and customer organisations (see Table 1). The interviews varied in length between 30 and 90 minutes, were recorded and transcribed. The interviewees were selected based on their involvement in the service operations and engagement with the collaboration partners. The data collection stopped when conceptual saturation was achieved (Yin 2009). Data was triangulated to mitigate bias and improve validity and case study rigour (Miles et al. 2014).

<Please insert Table 1 about here>

The semi-structured interviews were guided by a questionnaire covering a set of issues regarding the service operations and the companies' relationship. The discussed topics included business strategy and the global and local business environment, the nature of the service operations and organisation, and the inter-organisational relationships during the contract negotiations and after contract signature. The interviews did not specifically discuss uncertainty or the interviewees' uncertainty perception as this was found to bias interviewees in their discussions and thus reduce the usefulness of the gathered data (de Bruin et al. 2002). Rather it was aimed to uncover the sources of this uncertainty through the discussions by focusing on the areas of the business environment, technology, organisation and relationship. Specific topics were followed-up on and clarified to provide further depth. The interviews were conducted one-to-one in employees' offices, designated meeting rooms, or in exceptional cases via telephone or video conference.

\subsection{Data analysis}

The unit of analysis is the service within the dyad between provider and customer. The 
data were carefully analysed in two main steps to ensure internal and external validity (Eisenhardt 1989b, Barratt et al. 2011). First, a within-case analysis was performed via an in-depth data anlysis of each individual case using systematic combining (Dubois and Gadde 2002). This focused particularly on analysing uncertainty for each specific case representing a specific level fo service complexity. The data was coded initially in thematic categories based on the conceptual framework (Miles et al. 2014). Susequently, the data were coded based on the researchers' understanding and interpretation of the data. The case-specific coding structure merged from the empirical data by combining empirical data analysis, collection and the literature to facilitate theory building (Miles et al. 2014). Here, the depth of collected data and rigour of the analysis process ensured the truthfulness of the reported findings by linking observations of uncertainty perception to service complexity via the researchers' indepth understanding of the cases to ensure validity and reliability (Gibbert et al. 2008). Furthermore, each of the cases was written up as a case report and presented to the companies for verification and discussion to give an opportunity to comment on observations and initial conclusions. This ensured internal validity and allowed for further clarifications and refinements of the conclusions.

Second, cross-case analysis was conducted. Initially, we conducted a pairwise comparison (Eisenhardt 1989b) between the two maintenance-services cases and performance-based services cases to identify common characteristics for each specific level of service complexity. For this, the authors connected and compared codes from the within-case analysis in an iterative process to obtain a detailed and in-depth empirical description. Then, a cross-case comparison for all four presented cases was conducted (Eisenhardt 1989b). Here, the researchers investigated what changes in 
uncertainty perception between the cases could be attributed to the difference in service complexity via the in-depth understanding of each individual case (Gibbert et al. 2008). This step-by-step approach gave a full picture of the presented cases with regard to the research focus. Figure 1 depicts an excerpt of the coding structure that emerged in this process.

\section{<Please insert Figures 1 about here>}

\section{Within-case analysis}

\subsection{Maintenance services}

\subsubsection{Case A - Electronics}

The service contract of Case A was a maintenance contract including "on site overhaul \& testing, health checks (for the technical equipment) \& Preventative maintenance, (...) and firmware upgrades" (Company presentation, PA). It was the first formal framework service agreement with CA. Prior to the service agreement, PA had been available for necessary repairs on a case-by-case basis which helped them gain experience with service operations and the customer.

PA faced organisational, relational, and technological uncertainty. Organisational uncertainty arose from the nature of the service operations as the Service manager (PA) explained: "we had to change the dynamics of how we work. [For instance, we had to] get more service vehicles in [to cover our internal demand]." This differed from their product-focused business as the Service manager (PA) continued their description: "We do quite a lot of supply-only jobs, when we just supply them [a product] in a box and their engineers fit it." 
Relational uncertainty was connected to difficulties of accessing the customer site as the General manager (PA) exemplified: "an engineer would go to do the work and he wouldn't get access." This created tensions and disputes in the dyad in terms of assigning responsibility. Furthermore, PA received unnecessary service requests as the Service manager (PA) explained: "a lot of times, we get out there and all it was we had to change the battery, which is something they could or should be able to do." Thus, relational uncertainty was perceived predominantly by PA.

The technological uncertainty arose from the technological developments of new product lines as the Sales manager (PA) described: "[We have] the old range of actuators, there's still thousands out there. And then the new range of infra-red actuators." The new product range required different servicing and maintenance processes which were unknown to CA and thus led to unnecessary call-outs (see relational uncertainty above). Thus, it was the range of equipment offered by PA and the technological difference between them that created technological uncertainty.

\subsubsection{Case B - Water treatment}

PB saw services as a strategic source of business and a main potential for business growth. The General manager (PB) described: "We have a very aggressive plan to 2025 to grow. (...) As part of a huge sales organisation across the world, service is now becoming a huge factor not just for [us] but for a lot of sales companies." The case contract was the first agreement with $\mathrm{CB}$ but the two parties had previous servicerelated encounters as highlighted by the Service manager 2 (PB) "[the customer] just rung me up or he might ask for a bit of advice on the phone". Case B was thus a strategic business engagement for $P B$, similar to Case $A$. 
PB faced organisational, relational, and environmental uncertainty. PB's organisational uncertainty arose from the operational differences between production and services, however, they faced additional organisational uncertainty because they reorganised their back office and rotated staff between different roles to create task flexibility. As a result, the provider employees were uncertain in terms of their specific tasks and customer-specific processes as described by their Administrator 1 (PB) "Everyone was given redefined job roles to try and make things work a little better." This created additional organisational uncertainty for PB.

Relational uncertainty was perceived predominantly by CB and arose from the lack of communication regarding service visits as the Engineering Supervisor (CA) described: "there were visits [in the early stages] where an engineer has turned up unannounced. (...) I had to send the guy away because nobody knew who he was." This lack of communication resulted in various situations where the customer was unhappy with the service they received.

Environmental uncertainty arose from the security regulations regarding site access to the customer which required information in terms of the identity of the service engineers and their car registration. The Service manager (PB) explained: "the security is higher than normal. [This concerns access]. So it might be days that we might not be able to go."

\subsection{Performance-based services}

\subsubsection{Case C - Chemical production}

Case $\mathrm{C}$ focused on the performance-based operation and maintenance of a chemical production plant, including activities such as "ensuring a smooth, economic and efficient 
operation of the Plant, (...) and implementing and maintaining a high level of security, safety, housekeeping and environmental protection and health \& safety management systems" (Contract PC, p.10). For this purpose, PC had to provide dedicated plant staff working side by side with customer staff on the plant. The Head of O\&M Chemical (PC) described as follows: "It's like getting married in many respects." Thus, provider and customer operations were very interdependent for Case C.

Case $\mathrm{C}$ showed evidence of all four uncertainty types. Organisational uncertainty was particularly high in the planning of the service operations because substantial efforts were needed to hire staff and start-up operations. The Head of O\&M Chemical (PC) explained: "Each plant has a complete organisation of 200 to 300 people." These staff had to be hired after contract signature and before contract start, causing high levels of organisational uncertainty in the start-up phase. Once the "complete organisation" was put in place, PC experienced little organisational uncertainty because of their expertise in this area.

Relational uncertainty was low because the partners had a close relationship as the Vice President O\&M (PC) explained: "they tried to make us successful." From the interviews, it emerged that the relationship was a concern for PC, however, relational uncertainty was low.

Environmental uncertainty was related to the quality of material supply which varied substantially as the Quality control manager (PC) explained: "the actual raw material is different compared to [our plans]." This caused faster wearout of the equipment, increasing the cost of running the plant. Additional shortages in supply and disruptions of the supply chain with respect to energy and other production inputs arose. The Head O\&M Technical (PC) described: "(Diesel, oil, and gas) are a major 
problem now. (...) So most of our plants are not running at full capacity." Thus, the environmental uncertainty was connected specifically to the availability and quality of the supply to the service operations with shortages and disruptions casing problems in the service operations.

Technological uncertainty was relatively low as the Head of O\&M Chemical (PC) explained: "In fact, 95\% of the plant is low tech." Instead, most of the technological developments related to enabling the service through remote access technology as the Head of O\&M Chemical (PC) continued: "We are online connected with all our plants. It saves tickets of specialist to fly down. They're directly linked to our plants for troubleshooting. We can get all our key performance indicator figures in. We can benchmark. That's a product innovation and a new thing that nobody else is providing." Thus, technological uncertainty via digitalisation enabled PC to provide the engineering service more efficiently.

\subsubsection{Case D - Wind energy}

Service provision was a strategic part of PD's business as the Key Account Manager (PD) explained: "Our motivation for providing services is like any other maturing industry. Prices and margins go down on the equipment and then you have to extend your business and there is no better way. Chapter $1 A$ is service." Case D consisted of a longstanding relationship, however, with limited involvement between PD and CD. The Controlling Administration Manager (PD) explained: "The customer has 'some' engagement. (...) they have quite a few parks." Service visits required little direct interaction between provider and customer employees due to the physical location of the wind parks. 
Case D showed evidence of all four uncertainty types. Organisational uncertainty arose from the operational differences of services to manufacturing and was specifically connected to the lack of internal communications at PD. The Controlling administration manager (PD) explained: "There is a gap between service sales and service. (...) we are not a part of actually making the contract saying yes we can live up to this, but not to this." This gap between service sales and service operations created organisational uncertainty in terms of the specific service activities that needed to be performed for CD because service operations was not aware of the promises made by service sales. This uncertainty was further increased because most of PD's contracts contained nonstandard content as the Site manager (PD) described: "We need to know what to deliver, the promises that have been made." Thus, in Case D, organisational uncertainty arose from the manufacturing tradition of PD.

Relational uncertainty arose from the lack of communication between PD and CD as the Customer Service Manager (PD) explained: "The thing that is missing is communication. Our customers are not aware of what we are doing and we don't tell them." This lack of communication meant that PD refused to agree individualised service arrangement based on the customer's needs, lacking cooperation in regard to service operations, and a lack of addressing disagreements between provider and customer.

Environmental uncertainty was related to the growth of the renewable energy sector in Nordic countries and the cuts in government subsidies. The Managing director (CD) explained: "The prices were unhealthy, so that was the reason that we started for our services." This increased overall concern for operational costs in the sector, encouraging cost efficiency in operating the equipment. Furthermore, PD faced an 
increase in competition for small wind turbines which meant that PD strategically focused on the technological developments and support of larger turbines. The Key Account Manager (PD) described: "In Sales, if we had not adapted we would not have sold any turbines."

Technological uncertainty was connected to the increasing size and technological capabilities of wind turbines on the market. The Service controlling administration manager (PD) described: "Our strategy was to move away from small turbines. We are leaving that more and more." Thus, the technological development on the market led PD to focus their service business on larger infrastructure.

\section{Cross-case analysis}

Table 2 summarises the observations from the four presented cases and forms the basis for the cross-case comparison presented in this section. For the cross-case comparison, we approximated service complexity as a binary variable comparing maintenance services (relatively simple) to performance-based services (relatively complex). The cross-case comparison showed that some uncertainty types differed depending on the service complexity while other remained unaffected. Specifically, organisational uncertainty and relational uncertainty showed strong similarities between the four cases suggesting that these uncertainty types are not linked to service complexity. In contrast, our findings suggest a link between environmental and technological uncertainty with service complexity. These two uncertainty types were observed for both cases of performance-based services while there was only limited evidence in the maintenance-service cases.

<Please insert Table 2 about here> 
The findings regarding organisational uncertainty showed strong similarities between maintenance services and performance-based services. Organisational uncertainty arose from the difference between the production-based tradition of the provider and service operations. Important instances here were the change in work practices for service operations, internal communications between involved departments of the provider organisation and planning of service related activities. These findings suggest that organisational uncertainty was not linked to service complexity.

Similarly, the findings regarding relational uncertainty suggest that there was no relationship to service complexity. The observations differed between the four cases and showed differences between the two maintenance-service cases and the two cases of performance-based services respectively. For example, relational uncertainty in Case $C$ was low because of the constructive collaboration in the service dyad while in Case $D$ it was high because of a lack of communication between the partners. Thus, the findings suggest a strong dependence on relationship-specific factors such as the interaction between the provider and customer irrespective of service complexity.

The findings regarding environmental uncertainty suggest a link to service complexity. The observations of environmental uncertainty for performance-based services contained instances of supply uncertainty, market developments and competitor offerings. In contrast, maintenance services seemed to be predominantly affected by regulation changes. These findings suggest a link between service complexity and environmental uncertainty.

Similarly, our findings suggest a link between service complexity and technological uncertainty. The cases of performance-based services showed more 
extensive evidence of technological uncertainty in the form of new technologies that could extend the service offering and improve the efficiency of current service operations. An example was provided in Case C where PC utilised new developments of remote monitoring technologies to continuously monitor the health of their equipment and thus streamline processes of service provision. In comparison, the cases of maintenance services showed technological uncertainty in the form of evolving product technology which changed the requirements of operating and maintaining them. This suggests a positive relationship between service complexity and technological uncertainty.

\section{Discussion}

This research set out to investigate the link between service complexity and the uncertainty in service operations in engineering services. The findings showed that some uncertainty types (organisational and relational uncertainty) were not linked to service complexity, while other uncertainty types (environmental and technological uncertainty) were. This section derives four propositions based on the empirical findings as summarised in Figure 2.

\section{<Please insert Figure 2 about here $>$}

Our empirical findings suggest no relationship between service complexity and organisational uncertainty. This finding may be connected to the overall high operational complexity of engineering services in comparison to production (Kastalli and Van Looy 2013). Our research thus suggests that it is the engagement in engineering services in addition to production that creates organisational uncertainty for providers, not the level of service complexity of the specific offering. Reasons could be the 
increased need for information processing (Galbraith 2002) and the need for operational flexibility and heterogeneity (Kastalli and Van Looy 2013). Our findings suggest that the additional complexity of performance-based services does not increase the perceived organisational uncertainty from maintenance services. We thus formulate the following proposition:

Proposition 1: Engaging in engineering services increases the level of organisational uncertainty perceived by providers irrespective of service complexity.

Our empirical findings showed no link between service complexity and relational uncertainty. These findings contradict a prior study reported by Kreye et al. (2015) who found that providers of complex services need higher levels of relational capabilities to manage the closer engagement needed. Kreye et al.'s (2015) findings were based on the healthcare sector which is characterised by high levels of regulations specifying processes and responsibility and hence clarifying tasks and relationship of the service partners. This suggests that the industrial context may affect service relationships and the perceived relational uncertainty by defining (or lacking) a regulatory framework for inter-organisational engagements. Our findings also suggest that the perception of relational uncertainty may depend on the level of engagement within the specific service dyad. We can thus formulate the following proposition:

Proposition 2: The engagement between provider and customer defines the level of perceived relational uncertainty irrespective of service complexity.

Our findings suggest a positive link between service complexity and environmental uncertainty specifically in terms of the breadth of factors potentially influencing the provider's operations. This was exemplified through the varied observations for the two 
cases of performance-based services. The literature has highlighted environmental uncertainty for performance-based services only, describing particularly the difficulty of assessing the achieved outputs (Eisenhardt 1989a, Kim et al. 2007, Hypko et al. 2010, Nullmeier et al. 2016). Our findings indicate that increasing service complexity increases the provider's exposure to the customer's external environment including demand structures and supply in addition to their own environmental uncertainty. This presented research shows that the level and breadth of perceived environmental uncertainty increase, showing that the higher level of environmental uncertainty arises from various factors in the external environment such as regulation changes, supply availability and bottle necks (supply uncertainty), market developments and competitor offerings. We can thus formulate the following proposition:

Proposition 3: The level and breadth of perceived environmental uncertainty experienced by the provider is positively linked to service complexity.

Our findings further suggest a positive link between service complexity and technological uncertainty. Specifically, our cases suggest that performance-based services have a higher potential for technological uncertainty than maintenance services. The literature has limited description of technological uncertainty. However, descriptions of technological obsolescence particularly for performance-based services (Pince et al. 2015) are supported by the presented empirical work. We can thus formulate the following proposition:

Proposition 4: The provider's perceived technological uncertainty is positively linked to service complexity.

Interestingly, the higher levels of technological uncertainty in performance-based 
services led the provider to strengthen their service capabilities. Specifically, the service provider could utilise opportunities provided by the technological uncertainty to increase efficiency in service provision or add further depth to the provided service. An example was provided in Case C where PC utilised new developments of remote monitoring technologies to continuously monitor the health of their equipment and thus streamline processes of service provision. This suggest that although the technological uncertainty in service operations may be higher for performance-based services, the potential positive impact of this uncertainty (Carson et al. 2006) in terms of offering business opportunities is also potentially higher in comparison to maintenance services.

\section{Conclusions}

Engaging in engineering services remains an important challenge for companies and scholars alike. Although scholars have researched the existence of uncertainty in service operations (Durugbo and Erkoyuncu 2016, Kreye 2017b, Zhang and Banerji 2017), previous insights have focused on specific types of service offerings (Galbraith 2002, Nullmeier et al. 2016). This research explored the existence of uncertainty in service operations depending on service complexity, aiming to provide a more in-depth and nuanced understanding of engineering service operations. Our findings empirically demonstrate how different uncertainty types were perceived in settings of maintenance services and performance-based services respectively. Providing insights from four industrial cases, this research indicates that organisational and relational uncertainty were unaffected by service complexity while environmental and technological uncertainty increased with increasing service complexity. 
This research makes theoretical contributions to the area of service operations in a number of ways. First, we provide a conceptual framework detailing four uncertainty types in the provision of engineering services. This framework details relatively mature concepts in the literature such as organisational uncertainty (Simangunsong et al. 2012, Zhang and Banerji 2017) and environmental uncertainty (Hypko et al. 2010, Nullmeier et al. 2016) in addition to relatively new concepts such as relational uncertainty (Kreye 2017a). Specifically, technological uncertainty has not been defined or investigated in detail in the literature and our conceptual framework offers an operational conceptualisation of this concept in the context of engineering services.

Second, we provide in-depth insights on the potential relationship between service complexity and the four uncertainty types. The literature suggests a clear positive relationship between operational complexity and uncertainty (Davis 1993, van der Vorst and Beulens 2002), however, our findings suggest a more nuanced view depending on the specific uncertainty type. Here, it was specifically environmental and technological uncertainty that increased with increasing service complexity while the observations for organisational and relational uncertainty showed no such relationship.

Third, our research identified an important gap in knowledge concerning the link between service complexity and service innovation capabilities. Specifically, our research suggests a potentially positive effect of technological uncertainty in performance-based services in enabling the provider to develop new service offerings or provide existing offerings more efficiently. Such an effect was not observed for maintenance services. This suggests a self-reinforcing effect of increasing service complexity. 
In developing these contributions, we provide a framework of four testable propositions linking service complexity to the perception of four uncertainty types. This is a valuable contribution to the literature because it furthers theory building in the area of uncertainty management in engineering services. The framework furthermore offers providers of engineering services a basis for defining the service complexity of their offerings depending on the available organisational capabilities for managing relevant additional uncertainty.

\subsection{Managerial implications}

This research has important management implications for providers of engineering services. This provides managers with the ability to direct their managerial efforts and resources when increasing the complexity of their service offerings. Specifically, providers need to consider external sources of uncertainty (Simangunsong et al. 2016) such as environmental uncertainty and technical uncertainty because these uncertainty types increase with increasing service complexity. The increased environmental uncertainty arises from the closer dependence on the customer's operations with exposure to their external environments including supply and market developments. The increased technological uncertainty arises from the provider's higher dependence on equipment performance and interactions. Here, providers of performance-based services may benefit from the increased level of technological uncertainty to improve efficiency of service provision through, for example, reducing costs. This offers a specific possibility for new business opportunities and technological innovations. In contrast, internal sources of uncertainty (Simangunsong et al. 2016) such as organisational uncertainty remain unaffected by the service complexity. Providers of engineering 
services can thus focus their attention on managing external sources of uncertainty when they increase the level of service complexity from maintenance services to performance-based services.

\subsection{Limitations and future work}

The limitations of this research arise from the nature of case-based research, leaving important areas for future work. Case-based research has limited generalisability. We mitigated this by presenting multiple cases which enabled the replication of findings across cases (Voss et al. 2002). Furthermore, qualitative research has been linked to observer bias and subjectivity in data analysis (Yin 2009). We mitigated these limitations by applying a rigorous data analysis process via data triangulation between interview data and secondary data to improve the reliability (Yin 2009) and ensuring internal and external validity of the findings and conclusions (Barratt et al. 2011). Finally, our research is limited with regard to the investigation of service complexity which we simplified to the operational interdependence between provider and customer. More elaborate definitions of service complexity exist (Oliva and Kallenberg 2003, Tukker 2004, Lay et al. 2009, Van Ostaeyen et al. 2013) and further work is required to increase the breadth of research in this regard.

Further research is needed to expand the insights provided in this paper. First, future work needs to address the issue of technological uncertainty in engineering services and the potential for developing future business opportunities in this context. This paper provides an initial characterisation of technological uncertainty and future work needs to further these insights to offer actionable suggestions for service providers. Second, further research needs to establish a framework for suitable 
managerial responses to the different uncertainty types. This research suggests that environmental, technological, organisational, and relational uncertainty require different management approaches, however, more systematic evidence is needed. A targeted framework on suitable management activities to reduce the different uncertainty types would enrich theory development and support providers of engineering services. Third, further work is needed on the effect of service complexity on improving innovation capabilities of the service providers. This research suggests that the increased technological uncertainty of performance-based services can enable the provider to develop new technologies for more effective and/or efficient service provision. Further work is needed to link these insights to innovation management activities more generally.

\section{References}

Argyres, N. and Mayer, K. J., 2007. Contract Design as a Firm Capability: An Integration of Learning and Transaction Cost Perspectives. The Academy of Management Review, 32 (4), 1060-1077.

Badinelli, R., Barile, S., Ng, I., Polese, F., Saviano, M., and DiNauta, P., 2012. Viable service systems and decision making in service management. Journal of Service Management, 23 (4), 498-526.

Barratt, M., Choi, T. Y., and Li, M., 2011. Qualitative case studies in operations management: Trends, research outcomes, and future research implications. Journal of Operations Management, 29 (4), 329-342.

Bastl, M., Johnson, M., Lightfoot, H., and Evans, S., 2012. Buyer-supplier relationships in a servitized environment: An examination with Cannon and Perreault's framework. International Journal of Operations \& Production Management, 32 (6), 650-675.

Benedettini, O. and Neely, A., 2012. Factors influencing service complexity: the 
perspective of servitized manufacturers. In: EurOMA. Amsterdam, The Netherlands.

Benedettini, O., Neely, A., and Swink, M., 2015. Why do servitized firms fail? A riskbased explanation. International Journal of Operations \& Production Management, 35 (6), 946-979.

Bettencourt, L. A., Ostrom, A. L., Brown, S. W., and Roundtree, R. I., 2002. Client CoProduction in Knowledge-Intensive Business Services. California Management Review, 44 (4), 100-128.

Broekhuis, M., van Offenbeek, M., and Eissens-van der Laan, M., 2017. What professionals consider when designing a modular service architecture? International Journal of Operations \& Production Management, 37 (6), 748-770.

de Bruin, W. B., Fischbeck, P. S., Stiber, N. A., and Fischhoff, B., 2002. What Number is "Fifty-Fifty"?: Redistributing Excessive 50\% Responses in Elicited Probabilities. Risk Analysis: An International Journal, 22 (4), 713-723.

Carson, S. J., Madhok, A., and Wu, T., 2006. Uncertainty, opportunism, and governance: The effects of volatility and ambiguity on formal and relational contracting. Academy of Management Journal, 49 (5), 1058-1077.

Chao, X., Chen, H., and Zheng, S., 2009. Dynamic Capacity Expansion for a Service Firm with Capacity Deterioration and Supply Uncertainty. Operations Research, 57 (1), 82-93.

Davis, T., 1993. Effective Supply Chain Management. Sloan Management Review, 34, $35-46$.

Dubois, A. and Gadde, L. E., 2002. Systematic combining: An abductive approach to case research. Journal of Business Research, 55 (7), 553-560.

Durugbo, C. and Erkoyuncu, J. A., 2016. Mitigating uncertainty for industrial service operations: a multi case study. International Journal of Operations \& Production Management, 36 (5), 532-571. 
Eisenhardt, K. M., 1989a. Making fast strategic decisions in high-velocity environments. Academy of Management Journal, 32 (3), 543-576.

Eisenhardt, K. M., 1989b. Building theories from case study research. Academy of Management Review, 14 (4), 532-550.

Frei, F. X., 2006. Breaking the Trade-Off Between Efficiency and Service. Harvard Business Review, 84 (11), 92-101.

Galbraith, J. R., 1974. Organization Design: An Information Processing View. Interfaces, 4 (3), 28-36.

Galbraith, J. R., 2002. Organizing to Deliver Solutions. Organizational Dynamics, 31 (2), 194-207.

Gibbert, M., Ruigrok, W., and Wicki, B., 2008. What passes as a rigorous case study? Strategic Management Journal, 29 (13), 1465-1474.

Goel, R., 2007. Research spending under regulatory uncertainty. The Journal of Technology Transfer, 32 (6), 593-604.

Harland, C., Brenchley, R., and Walker, H., 2003. Risk in Supply Networks. Journal of Purchasing and Supply Management, 9 (2), 51-62.

Hawkins, T. G., Gravier, M. J., Berkowitz, D., and Muir, W. A., 2015. Improving services supply management in the defense sector: How the procurement process affects B2B service quality. Journal of Purchasing and Supply Management, 21 (2), 81-94.

Huikkola, T., Kohtamäki, M., and Rabetino, R., 2016. Resource Realignment in Servitization. Research-Technology Management, 59 (4), 30-39.

Hypko, P., Tilebein, M., and Gleich, R., 2010. Benefits and uncertainties of performancebased contracting in manufacturing industries. Journal of Service Management, 21 (4), 460-489.

Kastalli, I. V. and Van Looy, B., 2013. Servitization: Disentangling the impact of service business model innovation on manufacturing firm performance. Journal of 
Operations Management, 31 (4), 169-180.

Kim, S.-H., Cohen, M. A., and Netessine, S., 2007. Performance Contracting in After-Sales Service Supply Chains. Management Science, 53 (12), 1843-1858.

Kreye, M. E., 2017a. Relational uncertainty in service dyads. International Journal of Operations \& Production Management, 37 (3), 363-381.

Kreye, M. E., 2017b. Can you put too much on your plate? Uncertainty exposure in servitized triads. International Journal of Operations \& Production Management, 37 (12), 1722-1740.

Kreye, M. E., 2018. Interactions between perceived uncertainty types in service dyads. Industrial Marketing Management, DOI: 10.1016/j.indmarman.2018.04.014.

Kreye, M. E., Roehrich, J. K., and Lewis, M. A., 2015. Servitising manufacturers: the impact of service complexity and contractual and relational capabilities. Production Planning \& Control, 26 (14), 1233-1246.

Kurata, H. and Nam, S. H., 2013. After-sales service competition in a supply chain: Does uncertainty affect the conflict between profit maximization and customer satisfaction? International Journal of Production Economics, 144 (1), 268-280.

Lay, G., Schroeter, M., and Biege, S., 2009. Service-based business concepts: A typology for business-to-business markets. European Management Journal, 27 (6), 442-455.

Léo, P.-Y. and Philippe, J., 2001. Offer of Services by Goods Exporters: Strategic and Marketing Dimensions. The Service Industries Journal, 21 (2), 91-116.

Martinez, V., Bastl, M., Kingston, J., and Evans, S., 2010. Challenges in transforming manufacturing organisations into product-service providers. Journal of Manufacturing Technology Management, 21 (4), 449-469.

Melander, L. and Lakemond, N., 2015. Governance of supplier collaboration in technologically uncertain NPD projects. Industrial Marketing Management, 49, $116-127$. 
Miles, M. B., Huberman, A. M., and Saldaña, J., 2014. Qualitative Data Analysis: A Methods Sourcebook. 3rd ed. Thousand Oaks, CA, USA: Sage Publications, Inc.

Milliken, F. J., 1987. Three types of perceived uncertainty about the environment: State, effect, and response uncertainty. Academy of Management Review, 12 (1), 133143.

Mont, O. K., 2002. Clarifying the Concept of Product-service System. Journal of Cleaner Production, 10 (2002), 237-245.

Ng, I. C. L., Maull, R., and Yip, N., 2009. Outcome-based contracts as a driver for systems thinking and service-dominant logic in service science: Evidence from the defence industry. European Management Journal, 27 (6), 377-387.

Nordin, F., Kindström, D., Kowalkowski, C., and Rehme, J., 2011. The risks of providing services: Differential risk effects of the service-development strategies of customisation, bundling, and range. Journal of Service Management, 22 (3), 390408.

Nullmeier, F. M. E., Wynstra, F., and van Raaij, E. M., 2016. Outcome attributability in performance-based contracting: Roles and activities of the buying organization. Industrial Marketing Management, 59, 25-36.

Oliva, R. and Kallenberg, R., 2003. Managing the transition from products to services. International Journal of Service Industry Management, 14 (2), 160-172.

Van Ostaeyen, J., Van Horenbeek, A., Pintelon, L., and Duflou, J. R., 2013. A refined typology of product-service systems based on functional hierarchy modeling. Journal of Cleaner Production, 51, 261-276.

Pince, C., Frenk, J., and Dekker, R., 2015. The Role of Contract Expirations in Service Parts Management. Production and Operations Management, 24 (10), 1580-1597.

Reim, W., Parida, V., and Sjödin, D. R., 2016. Risk management for product-service system operation. International Journal of Operations \& Production Management, $36(6), 665-686$. 
Rindfleisch, A. and Heide, J. B., 1997. Transaction Cost Analysis: Past, Present, and Future Applications. Journal of Marketing, 61 (4), 30-54.

Roehrich, J. K. and Lewis, M. A., 2014. Procuring Complex Performance: Implications for Exchange Governance Complexity. International Journal of Operations \& Production Management, 32 (2), 221-241.

Selviaridis, K., 2016. Contract functions in service exchange governance: evidence from logistics outsourcing. Production Planning and Control, 27 (16), 1373-1388.

Settanni, E., Newnes, L. B., Thenent, N. E., Parry, G. C., Bumblauskas, D., Sandborn, P., and Goh, Y. M., 2016. Applying Forgotten Lessons in Field Reliability Data Analysis to Performance-Based Support Contracts. Engineering Management Journal, 28 (1), 3-13.

Siggelkow, N., 2007. Persuasion with case studies. Academy of Management Journal, 50 (1), 20-24.

Simangunsong, E., Hendry, L. C., and Stevenson, M., 2012. Supply-chain uncertainty: a review and theoretical foundation for future research. International Journal of Production Research, 50 (16), 4493-4523.

Simangunsong, E., Hendry, L. C., and Stevenson, M., 2016. Managing supply chain uncertainty with emerging ethical issues. International Journal of Operations \& Production Management, 36 (10), 1272-1307.

Tukker, A., 2004. Eight types of Product-Service System; eight ways to sustainability? Experiences from SUSPRONET. Business Strategy and the Environment, 13 (4), 246260.

Ulaga, W. and Kohli, A. K., 2018. The role of a solutions salesperson: Reducing uncertainty and fostering adaptiveness. Industrial Marketing Management, 69 (February), 161-168.

Vandermerwe, S. and Rada, J., 1988. Servitization of Business: Adding Value by Adding Services. European Management Journal, 6 (4), 314-324. 
Vargo, S. L., 2008. Customer integration and value creation: paradigmatic traps and perspectives. Journal of Service Research, 11 (2), 211-215.

van der Vorst, J. and Beulens, A., 2002. Identifying sources of uncertainty to generate supply chain redesign strategies. International Journal of Physical Distribution \& Logistics Management., 34 (1), 6-24.

Voss, C., Tsikriktsis, N., and Frohlich, M., 2002. Case research in operations management. International Journal of Operations \& Production Management, 22 (2), 195-219.

Wise, R. and Baumgartner, P., 1999. Go Downstream: The New Profit Imperative in Manufacturing. Harvard Business Review, 77 (5), 133-141.

Yang, M. and Gabrielsson, P., 2017. Entrepreneurial marketing of international high-tech business-to-business new ventures: A decision-making process perspective. Industrial Marketing Management, 64, 147-160.

Yang, W., Gao, Y., Li, Y., Shen, H., and Zheng, S., 2017. Different roles of control mechanisms in buyer-supplier conflict: An empirical study from China. Industrial Marketing Management, 65 (December 2015), 144-156.

Yin, R. K., 2009. Case study research: design and methods. Los Angeles, CA, USA: SAGE Publications.

Zhang, W. and Banerji, S., 2017. Challenges of servitization: A systematic literature review. Industrial Marketing Management, 65 (June), 217-227.

Zou, W., Brax, S. A., and Rajala, R., 2018. Complexity and its dimensions in the servitization litertaure: A systematic review. In: Spring Servitization Conference. Copenhagen, Denmark. 


\section{Tables and Figures}

Table 1: Data collection for four cases

\begin{tabular}{|c|c|c|c|c|}
\hline & \multicolumn{2}{|c|}{ Maintenance service } & \multicolumn{2}{|c|}{ Performance based service } \\
\hline & Case A & Case B & Case C & Case D \\
\hline Sector & $\begin{array}{l}\text { European } \\
\text { electronics sector }\end{array}$ & $\begin{array}{l}\text { European water } \\
\text { treatment sector }\end{array}$ & $\begin{array}{l}\text { Global chemical } \\
\text { production sector }\end{array}$ & $\begin{array}{l}\text { European Wind } \\
\text { energy sector }\end{array}$ \\
\hline Provider & $\begin{array}{l}\text { Manufacturer of } \\
\text { control systems } \\
\text { such as actuators } \\
3,500 \text { employees } \\
\text { Revenue: } 670 \mathrm{m€}\end{array}$ & $\begin{array}{l}\text { Manufacturer of } \\
\text { water treatment } \\
\text { pumps } \\
\text { 18,900 employees } \\
\text { worldwide } \\
\text { Revenue: } 3 \text { b€ }\end{array}$ & $\begin{array}{l}\text { Manufacturer of } \\
\text { plants and plant } \\
\text { equipment } \\
\text { 13,000 employees } \\
\text { Revenue: } 2.7 \text { b€ }\end{array}$ & $\begin{array}{l}\text { Manufacturer of } \\
\text { wind energy } \\
\text { production } \\
\text { equipment } \\
21,500 \text { employees } \\
\text { Revenue: } 8.4 \text { b€ }\end{array}$ \\
\hline $\begin{array}{l}\text { Time spent on } \\
\text { provider site }\end{array}$ & 1 day & 2 days & 4 days & 2 days \\
\hline $\begin{array}{l}\text { Provider } \\
\text { interviewees }\end{array}$ & $\begin{array}{l}\text { Service engineer } \\
\text { Sr Service engineer } \\
\text { Service manager } \\
\text { Sales manager } \\
\text { General manager }\end{array}$ & $\begin{array}{l}\text { Service engineer } 1 \\
\text { Service engineer } 2 \\
\text { Service engineer } 3 \\
\text { Administrator } 1 \\
\text { Service planner } \\
\text { Service coordinator } \\
\text { Office manager } \\
\text { Sales manager } 1 \\
\text { Sales manager } 2 \\
\text { (semi-retired) } \\
\text { Accounts manager } \\
\text { Service manager } 1 \\
\text { General manager }\end{array}$ & $\begin{array}{l}\text { Vice President O\&M } \\
\text { Head O\&M } \\
\text { Chemical } \\
\text { General manager } \\
\text { O\&M Sales } \\
\text { Performance } \\
\text { manager } \\
\text { Procurement } \\
\text { manager } \\
\text { Mechanical } \\
\text { maintenance } \\
\text { manager } \\
\text { Operations director } \\
\text { General } \\
\quad \text { maintenance } \\
\text { manager } \\
\text { Material manager } \\
\text { Regional finance } \\
\text { manager }\end{array}$ & $\begin{array}{l}\text { Manager of } \\
\text { Customer Service } \\
\text { Customer Service } \\
\text { Manager } 1 \\
\text { Customer Service } \\
\text { Manager } 2 \\
\text { Customer Service } \\
\text { Manager } 3 \\
\text { Controlling } \\
\text { Administration } \\
\text { Manager } \\
\text { Regional Manager } \\
\text { Site Manager } \\
\text { Quality } \\
\text { Performance Expert } \\
\text { Senior Business } \\
\text { Manager }\end{array}$ \\
\hline Customer & $\begin{array}{l}\text { Operator of water } \\
\text { treatment facilities }\end{array}$ & $\begin{array}{l}\text { Operator of } \\
\text { national } \\
\text { government } \\
\text { building } \\
\end{array}$ & $\begin{array}{l}\text { Producer of } \\
\text { chemical products }\end{array}$ & $\begin{array}{l}\text { Provider of Electric } \\
\text { energy from } \\
\text { renewable sources }\end{array}$ \\
\hline $\begin{array}{l}\text { Time spent on } \\
\text { customer site }\end{array}$ & 1 day & 1 day & 1 day & 1 day \\
\hline $\begin{array}{l}\text { Customer } \\
\text { interviewees }\end{array}$ & $\begin{array}{l}\text { Electrician } 1 \\
\text { Electrician } 2 \\
\text { Technical manager } \\
1 \\
\text { Technical manager } \\
2 \\
\text { Eng. Supervisor }\end{array}$ & $\begin{array}{l}\text { Mechanical } \\
\text { engineer } \\
\text { Engineering } \\
\text { Supervisor } \\
\text { Administrator } 2 \\
\text { Service manager } 2\end{array}$ & $\begin{array}{l}\text { Chief operation } \\
\text { officer } \\
\text { Plant manager } \\
\text { Technical director } \\
\text { Production \& } \\
\text { process manager } \\
\text { Maintenance } \\
\text { manager } \\
\text { Quality control } \\
\text { manager } \\
\text { HSE manager }\end{array}$ & $\begin{array}{l}\text { Service Operations } \\
\text { Manager } \\
\text { Operations Manager } \\
\text { Procurement and } \\
\text { Project Manager } \\
\text { Managing Director }\end{array}$ \\
\hline
\end{tabular}


Table 2: Observed uncertainty types across studied dyads

\begin{tabular}{|c|c|c|c|c|}
\hline & \multicolumn{2}{|c|}{ Maintenance services } & \multicolumn{2}{|c|}{ Performance based services } \\
\hline & Case A & Case B & Case C: Chemical & Case D:Wind energy \\
\hline $\begin{array}{l}\text { Organisational } \\
\text { uncertainty }\end{array}$ & $\begin{array}{l}\text { Changing work practices from } \\
\text { manufacturing to service } \\
\text { provision }\end{array}$ & $\begin{array}{l}\text { Changing work practices from } \\
\text { manufacturing to service } \\
\text { provision } \\
\text { Creating job flexibility in } \\
\text { back-office operations } \\
\text { through job rotations and } \\
\text { role redefinitions }\end{array}$ & $\begin{array}{l}\text { High workload in front-end to } \\
\text { build the local organisations } \\
\text { to operate and maintain the } \\
\text { plant once contract is signed }\end{array}$ & $\begin{array}{l}\text { Lack of internal information } \\
\text { processing between PD 's } \\
\text { internal departments of } \\
\text { service sales, project } \\
\text { management and service } \\
\text { operation }\end{array}$ \\
\hline $\begin{array}{l}\text { Relational } \\
\text { uncertainty }\end{array}$ & $\begin{array}{l}\text { Ad hoc difficulties between } \\
\text { the partners in the form of, } \\
\text { e.g. lack of site access } \\
\text { Call-out for non-contractual } \\
\text { service activities of Provider } \\
\text { A's service engineers }\end{array}$ & $\begin{array}{l}\text { Lacking information } \\
\text { processing between partners } \\
\text { due to inability of PB to build } \\
\text { personal customer contacts } \\
\text { on administrative level }\end{array}$ & $\begin{array}{l}\text { Close collaboration due to } \\
\text { joint goal of making and } \\
\text { keeping the plant operable }\end{array}$ & $\begin{array}{l}\text { Regular disagreements with } \\
\text { CD because of lack of } \\
\text { communication between the } \\
\text { partners in terms of provided } \\
\text { service activities, and PD's } \\
\text { lack of resolving these } \\
\text { disagreements }\end{array}$ \\
\hline $\begin{array}{l}\text { Environmental } \\
\text { uncertainty }\end{array}$ & No instances observed & $\begin{array}{l}\text { Regulatory changes regarding } \\
\text { safety of customer site access }\end{array}$ & $\begin{array}{l}\text { Variations in quality of supply } \\
\text { materials from local supplier } \\
\text { created increased wear and } \\
\text { tear of the equipment and } \\
\text { thus increased need for } \\
\text { maintenance and repair }\end{array}$ & $\begin{array}{l}\text { Growth of renewable energy } \\
\text { sector with cuts of } \\
\text { government subsidies } \\
\text { Increasing amount of } \\
\text { competitors for wind turbines }\end{array}$ \\
\hline $\begin{array}{l}\text { Technological } \\
\text { uncertainty }\end{array}$ & $\begin{array}{l}\text { New product range with } \\
\text { different requirements for } \\
\text { operation and maintenance }\end{array}$ & No instances observed & $\begin{array}{l}\text { Technological developments } \\
\text { regarding remote controlled } \\
\text { access to the equipment for } \\
\text { gaining performance data }\end{array}$ & $\begin{array}{l}\text { Increasing size and } \\
\text { technological capabilities of } \\
\text { renewable energy technology }\end{array}$ \\
\hline
\end{tabular}




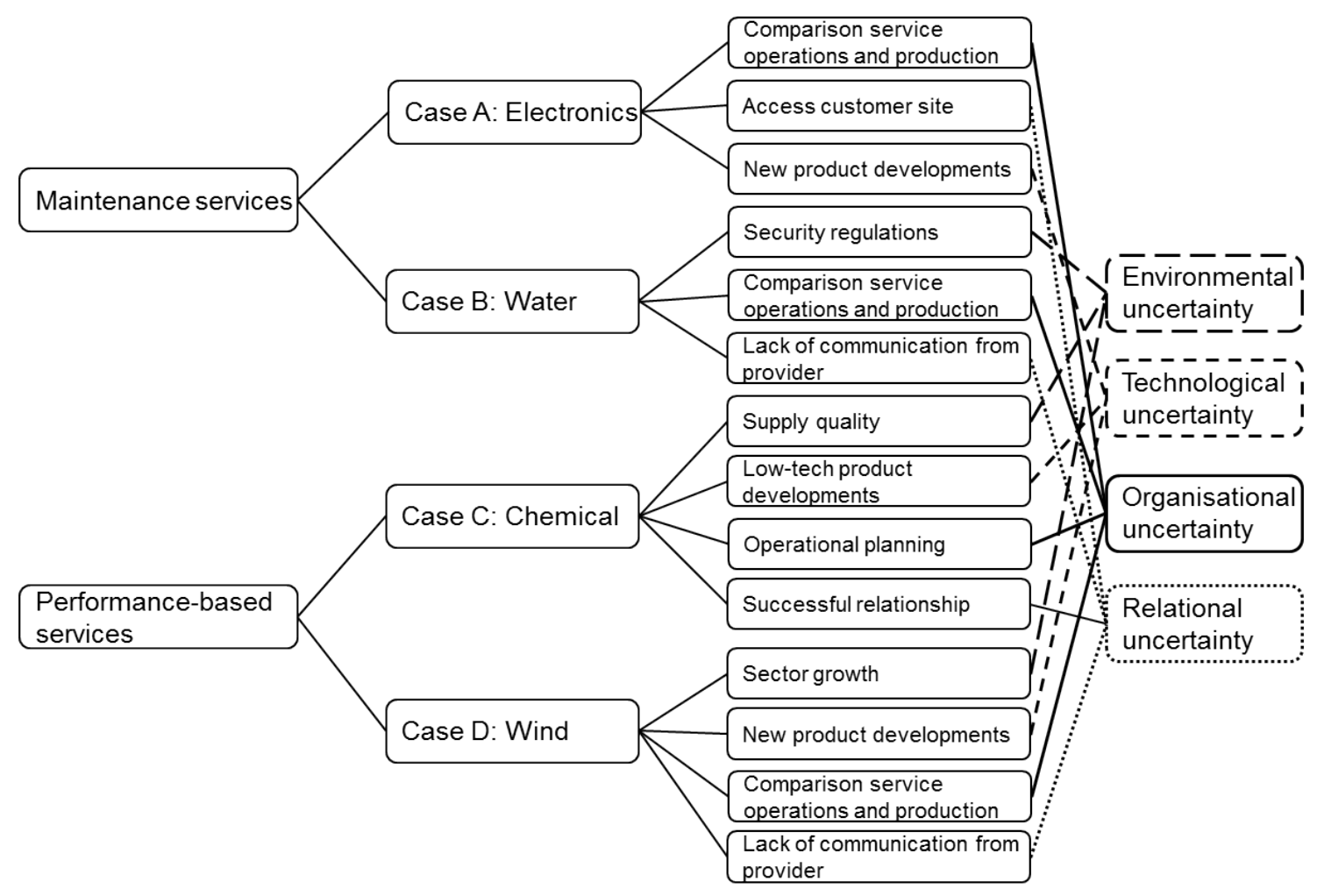

Figure 1: Excerpt of coding structure

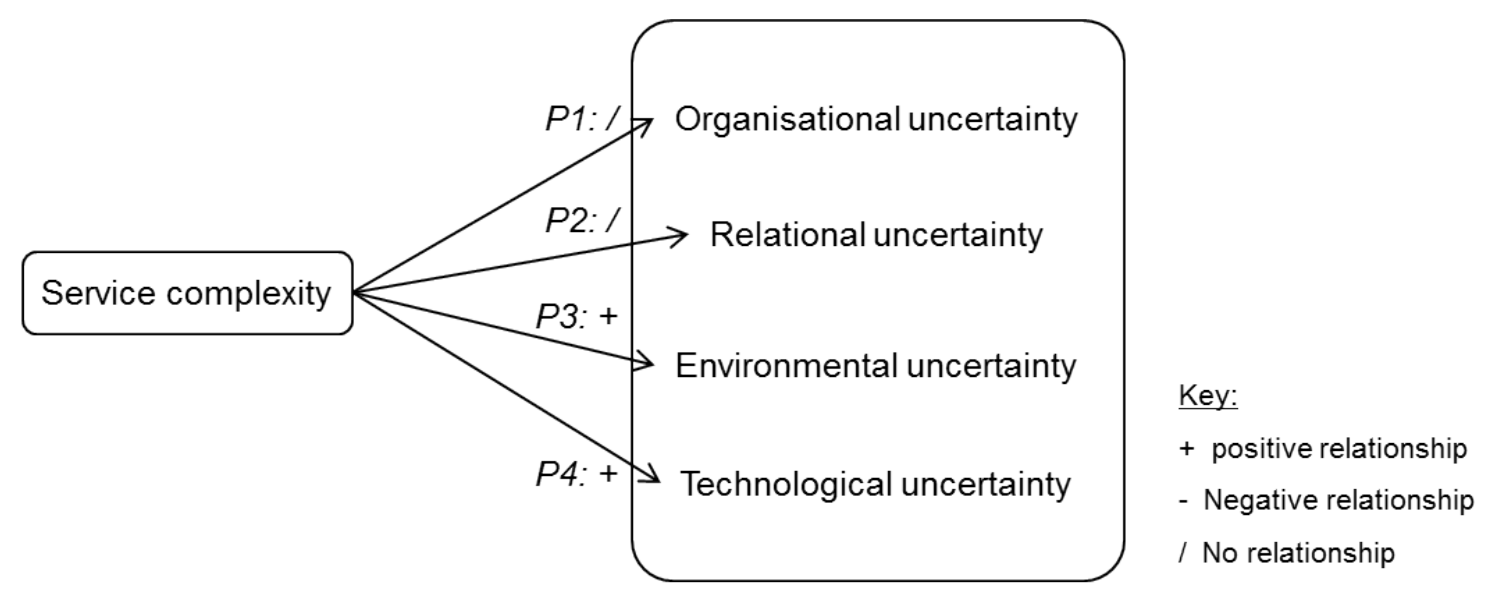

Figure 2: Propositions linking uncertainty to service complexity in engineering service provision 